\title{
THE PROBLEMS OF EXPERT WITNESS IN CRIMINAL LAW ${ }^{1}$
}

\author{
Rafiqa Qurrata A'yun*
}

* Alumnus of Post Graduate Program Faculty of Law Universitas Indonesia

\section{Article Info}

Received : 2 November 2014 | Received in revised form : 16 December 2014 | Accepted :30 December 2014 Corresponding author's e-mail : rafiqa.qurrata@gmail.com

\begin{abstract}
The expert testimony is a potential problem in the future due to the impact of the advancement of science and technology. This paper examines the place of expert witness to be considered as one of the evidence in criminal case investigation and criminal court. It is argued that expert qualifications should be determined based on formal education, professional experiences, and the relevance of his expertise with the case. The Criminal Procedure Code (KUHAP) does not restrict the necessary knowledge, so that the expert testimony about criminal law can also become evidence. However, as one of the evidence that can punish or relieve someone, a testimony stated by an expert should be neutral and objective. This study is descriptive analytic using normative juridical literature and empirical data. It also uses the primary data through guided in-depth interview to the judges, public prosecutors, lawyers, and criminal law experts.
\end{abstract}

Keywords: expert witness, criminal law, impartiality, conflicting opinion, ius curia novit

\begin{abstract}
Abstrak
Kesaksian ahli akan menjadi persoalan di masa mendatang karena adanya perkembangan ilmu pengetahuan dan teknologi. Tulisan ini membahas mengenai posisi saksi ahli yang dipertimbangkan sebagai salah satu bukti yang digunakan dalam penyelidikan kasus pidana dan peradilan pidana. Tulisan ini berargumentasi bahwa kualifikasi ahli harus ditentukan berdasarkan pendidikan formal, pengelaman profesional, dan relevansi keahlian terhadap kasus yang ditangani. Karena Kitab Undang-Undang Hukum Acara Pidana (KUHAP) tidak membatasi pengetahuan yang diperlukan, maka kesaksian ahli mengenai hukum pidana juga dapat dipandang sebagai bukti. Akan tetapi, sebagai salah satu bukti hukum yang dapat digunakan untuk menghukum atau membebaskan seorang terdakwa, kesaksian harus berdasarkan argument ilmiah. Studi ini adalah analisis deskriptif menggunakan literatur hukum normatif dan data empirik. Selain itu, studi ini juga menggunakan data primer yang dikumpulkan melalui wawancara mendalam yang terstruktur kepada para hakim, jaksa, pengacara, dan ahli hukum.
\end{abstract}

Kata Kunci: saksi ahli, hukum pidana, imparsialitas, pertentangan pendapat, ius curia novit

\section{Introduction}

As the negative impact of the advancement of science and technology will lead to make the crime method become more complex, it will also be followed by problems related to the verification process of the crime. To illustrate, some problems that need an advancement of verification process are cyber crime, banking criminal acts, election crime, and so on. Thus, to address this issue, expert testimony based on special and

${ }^{1}$ This article is rewritten from master thesis in Post Graduate Program Faculty of Law, Universitas Indonesia, entitled "The Qualification and Objectivity of The Expert in Criminal Cases". Thanks to Prof. Topo Santoso as my thesis supervisor. 
specific knowledge will be very important to reveal the truth. For example, forensic medical experts, information technology experts, language experts, and geologists have special knowledge and skill which are not mastered by law enforcers. Moreover, specific legal experts sometimes presented in the court due to the development of regulations and specialization of law experts.

Based on that background, this paper discusses the place of expert witness in the criminal examination. Special knowledge owned by some expert can help to understand the case better. The code of criminal procedure (KUHAP) sets forth that expert testimony can be used from the investigation process until the trial. In the court, it even has placed as one of the evidence to be considered by the judge.

However based on the research results, there are four possible problems regarding the place of expert witnesses. First, expert testimony in the trial is not necessarily considered to be important since the value of this evidence is not binding. Second, the development of the criminal examination will lead the judge to summon not only the non-legal experts, but also the criminal-law experts. This is actually contradict with the principle of the criminal law ius cruia novit which means that the judge is the law expert who are generalist and are considered master the law. Third, the nature of scientific truth, especially in the social sciences which are multi-paradigm can also become a problem for the judge due to the diversity of perspectives in the interpretation of the cases. Fourth, the place of the expert witness as the evidence that can convict or release a person has the potential to be misused by the party who summon them. This is associated with the objectivity of knowledge and integrity of the expert witnesses.

Using normative legal method, this paper addresses some research questions. First, in attempt to understand the position of expert witness in the code of criminal procedure in Indonesia, the author uses legal theory and expert opinion as references to analyze the problems. Second, in analyzing the debate on the place of expert testimony related to the principle ius curia novit, the author interviewed both the scholars and the practitioners of the criminal procedure law. Third, related to the contradictive perspective of expert opinion that becomes an issue in criminal investigation, the author interviewed practitioners of criminal procedure law as well as included some case studies obtained from mass media. Fourth, the author also analyzes the potential bias of the truth claimed by the expert by conducting interview and using some case study from the mass media.

\section{The Place of Expert Witness}

The Criminal Procedure Code (KUHAP) explains the expert witness in General Regulation Chapter, especially in Article 1 item 28 that states: "expert witness is the information given by a person who has special expertise in the necessary things to make light of a criminal offense for the purpose of inspection". It also says that the expert witness may be submitted during the investigation process as well as in the court. Article 120 paragraphs (1) of the Criminal Procedure Code states: "anytime when investigator considers necessary, he can ask the opinion of the experts or people who have special skills". The explanation section of the article does not explain further on how the expert opinion is required and how the position of people who have special skills. However, according to M Karjadi and R Soesilo, 'the experts' are meant for example a radio mechanic or car mechanic. Meanwhile, 'people who have 
special skills' are meant for example an astrologer, astronomer, and so on. Theycanbe examinedasanordinarywitnesswithoutbeing swornorconsultedasan expertas long astheswornis beforehand. ${ }^{2}$

Article 184 paragraph (1) of the Criminal Procedure Code states the expert witness as evidence. This regulation is followed by the Article 186 that states the expert witness as information stated in the court. From the article, according to Karjadi and Soesilo the evidence of expert testimony is not what the experts explain to the investigators or persecutors, rather the information stated by the expert in the court after he took an oath in front of the judge.

Black's Law Dictionary explains testimonial evidence as "a person testimony offered to prove the truth of the matter asserted, especially evidence elicited from a witness". ${ }^{3}$ It means testimonial evidence is a testimony stated by a person to prove the truth claims, especially evidence showed by the witness. Meanwhile, what is meant by 'expert evidence' is "evidence about a scientific, technical, professional, or other specialized to testify because of familiarity with the subject or special training in the field, also termed expert testimony."

Furthermore, the term expert testimony defines as "opinion evidence of some person who posseses special skill or knowledge in some science, profession or business which is not common to the average man and which is possesed by the expert by reason of his special study or experience. ${ }^{5} \mathrm{~A}$ similar definition is also affirmed by West's Legal Thesaurus that explains the expert testimony as "the opinion evidence of a person who possesses special skill or knowledge in some science, profession, or business that is not common to the average person." 6 Curzon in Dictionary of Law defines expert evidence as referred to Civil Procedure Rules (CPR), as follows:

An 'expert' under CPR, Part 35, is one who has been instructed to give or prepare evidence for the purpose of court proceedings: $r$ 35.2. Expert evidence should be restricted to that which is reasonably required to resolve proceedings: $r$ 35.1. The expert has a duty to help the court, and this overrides any obligation to the person from whom he has received instructions or by whom he is paid: $r$ 35.3. No party may call an expert or put his report in evidence without the court's permission, and the court may limit fees and expenses that the party who wishes to rely on the expert may recover from any other party: $\mathrm{r} 35.4(4) .^{7}$

\section{III.Expert Qualification in the Examination Processes}

According to Mardjono Reksodiputro, the increase number of crime, the changing pattern of the assessment of the offenders, as well as the emergence of new form of crime are parts of social change caused by development programs in Indonesia. To overcome this, studies and research are needed to reveal new facts or examines

${ }^{2}$ Kitab Undang-Undang Hukum Acara Pidana, (Criminal Procedure Code) UU No. 8 Tahun 1981. Disusun oleh M Karjadi dan R Soesilo dalam Kitab Undang-Undang Hukum Acara Pidana dengan Penjelasan Resmi dan Komentar. Cet. 3. Bogor: Politeia, 1997,p. 109.

${ }^{3}$ Garner, Bryan A. Ed. Black's Law Dictionary. Eight Edition. (St. Paul: West Publishing Co., 2004), p. 600 .

${ }^{4}$ Ibid., p. 597.

${ }^{5}$ Black, loc.cit.

${ }^{6}$ William Statsky, Legal Thesaurus/Dictionary, (St. Paul: West Publishing Co., 1985), p. 300.

${ }^{7}$ LB Curzon, Dictionary of Law. Sixth Edition, (Essex: Pearson Education Limited, 2002), p. 168. 
already known facts in a new perspective. ${ }^{8}$ Referred to that opinion, changes related to the criminal law enforcement can be anticipated by science.

Yahya Harahap also mentions the relationship between the changing of the criminal procedure law and of the science. According to him, the development of science and technology influence the quality of crime methods, so that it should be balanced by developing the quality and methods of evidence using science and expertise. ${ }^{9}$

Therefore, by mentioning expert testimony in the Criminal Procedure Code, the role of the expert cannot be ignored both in the investigation processes and in the court. For prosecutor as Sarjono Turin, expert testimony is very useful in the process of proving corruption cases that are handled. First, the expert is needed because the prosecutor, defense counsel, and judges have limited knowledge. Sometimes, the criminal proceeding is related to other discipline of science which is not mastered by the law enforcers. Second, expert witness is useful to convince the judge and the defendant along with the counsels when the evidence which is presented less than optimal. For example, in an attempt to prove the act of bribery, prosecutors tend to have minimal evidence generally in the form of a sound recording wiretapping. To ensure whose voice on the tape, then the prosecutor will summon a sound expert. ${ }^{10}$

For Maqdir Ismail, a lawyer who are often presented expert witnesses in court room, an expert is needed to maintain objectivity. He also assess that an expert will only stand for the truth based on his knowledge and expertise. Thus, an expert is considered as a neutral party that can give clear opinion and not confined to the assumption of the charge filed by the prosecutor. ${ }^{11}$

Meanwhile, in the Criminal Procedure Code the urgency of expert testimony is not clearly defined. Article 1 item 28 defines very shortly that expert witness is needed to make clear of a criminal case in the court. Who is intended as an expert is not described further, but it has demonstrated the role of the expert in the verification process in the court. As a person who has special knowledge and expertise, an expert is considered special among other people, including the law enforcers. This advantage can be utilized in an effort to investigate and decide criminal case.

Chairul Huda, a criminal law expert who often testified in the court believes an expert (in this case is legal experts such as himself) is required to gain an understanding of the theoretical law. For example, the science of law under its control is necessary because law enforcement can not merely be based on the provisions of the law. The application of the law requires a theoretical understanding which sometimes not written in the text or has been in the book but still debatable. Thus, to gain the understanding the law expert is needed.

From this, expert testimony then becomes important for such party in obtaining the judge's conviction. The ability of an expert to explain issues related to his

${ }^{8}$ Mardjono Reksodiputro, "Survei dan Riset untuk Sistem Peradilan Pidana yang Lebih Rasional (Survey and Research for Criminal Justice System to be more Rational)," in Kriminologi dan Sistem Peradilan Pidana; Kumpulan Karangan Buku Kedua (Criminology and Criminal Justice System; Collected Writing, Second Book), (Jakarta: Pusat Pelayanan Keadilan dan Pengabdian Hukum, 2007), p. 100.

${ }^{9}$ Harahap, M Yahya. Pembahasan Permasalahan dan Penerapan KUHAP; Penyidikan dan Penuntutan (Study on the Problem and Implementation of Criminal Procedure Code: Investigation and Prosecution. 4th Edition. Jakarta: Sinar Grafika, 2002.

${ }^{10}$ Interview with Sarjono Turin, a prosecutor of the commission of combating corruption (KPK),11 March 2010 at the corruption court in the district court of Central Jakarta, Uppindo Building, Jakarta.

${ }^{11}$ Interview with Maqdir Ismail, 25 February 2010, at his office in Jalan Bandung No. 4, Menteng, Jakarta. 
scientific knowledge are one of the efforts to convince the judge that can be done by the defendant and counsel. Chairul Huda explains this by referred to the Criminal Procedure Code which states that regulation applicable to the witness is also relevant to the expert. To illustrate, if the Criminal Procedure Code determines the defendant is entitled to file any defense witnesses or a de charge witnesses for the purpose of defense, the defendant may also propose experts for the same purpose though the Code does not recognize the term $a$ de charge expert. ${ }^{12}$

Harvard Law Review Association assesses the ability of experts to help the case investigation is the basis for determining the important of expert testimony. The provisions in Rule 702 of the Federal Rules of Evidence which are applicable in the United States said the expert testimony is acceptable if it can help the judges carry out their duties.

The guiding principle of the body of rules governing the admissibility of expert testimony is helpfullness: to be admissible, expert testimony must be helpful. Rule 702 of the Federal Rules of Evidence, for example, permits qualified experts to testify about their specialized knowledge only when the testimony will assist the trier of fact in understanding the evidence or in determining a fact in issue. ${ }^{13}$

That description indicates an affirmation of experts who can deliver testimony is the expert who truly qualified and experts who can help the process of verification. The role of experts would be more important if the case which is examined related to the field of science that is not mastered by law enforcers. Thus, the expert may also be ignored if its presence does not help the case investigation.

According to the Corruption Court judge, I Made Hendra Kusuma, to include expert testimony as one of the judges' consideration, the information must be contextually analyzed. If the expert testimony is relevant to the subject matter, it will be used. But if otherwise, the judge will not use it. During his time as a judge, Made Hendra has never asked to present expert testimony. Generally, experts presented by the prosecution or the accused. Made Hendra argues, the Criminal Procedure Code determines the evidentiary value of expert testimony which is not binding or freely used by judges. ${ }^{14}$ It means, the judges do not obliged to follow the opinion and conclusion of experts when in conflict with judges' conviction. ${ }^{15}$

A similar opinion is also stated by other Corruption Court judge, Slamet Subagyo, by referring to Article 183 of the Criminal Procedure Code as follows: "Judges should not decide a criminal case unless with at least two valid evidences to gain confidence that a criminal act really occurred and that the defendant is guilty of committed crime". ${ }^{16}$ Slamet interprets this provision indicates the judge only requires two witnesses and the conviction to decide a criminal case. In other words, the existence of an expert can be considered merely as a supplement or simply add the judge's conviction. ${ }^{17}$

${ }^{12}$ Interview with Chairul Huda, a criminal law expert, 15 March 2010, at Pascasarjana Building Universitas Muhammadiyah Jakarta Ciputat, Jakarta Selatan.

13 The Harvard Law Review Associaton, "Expert Legal Testimony," Harvard Law Review Vol. 97 No. 3 (January 1984): 797.

${ }^{14}$ Interview with I Made Hendra Kusuma, a corruption court judge, 11 March 2010, at Uppindo Building, Jakarta.

${ }^{15}$ Prodjohamidjojo, Martiman. Kemerdekaan Hakim; Keputusan Bebas Murni (Arti dan Makna) (Judge Freedom: Released Decision, Definition and Meaning). Jakarta: Simplex, 1984.

${ }^{16}$ Indonesia [b], Undang-Undang Hukum Acara Pidana, UU No. 8 tahun 1981, LN No. 76 Tahun 1982, TLN No. 3209, P. 183.

${ }^{17}$ Interview with Slamet Subagyo, a corruption court judge, 11 March 2010, at Uppindo Building, 
Therefore, expert testimony might be ignored due to the Criminal Procedure Code is more emphasis the value of evidence in the hands of the judges.

For Maqdir Islamil, although judges give opportunity to experts to be heard, but sometimes it impresses that the testimony is ignored by the judges. This attitude is unfortunate by Maqdir since the Criminal Procedure Code has determined the expert testimony as valid evidence. In contrast, according to Sarjono Turin, a prosecutor of commission of combating corruption (KPK), the authority of the judges to waive the expert testimony in legal consideration cannot be blamed. The reason is the Criminal Procedure Code does not determine a judge to fixate on expert testimony submitted by the prosecutors or defence counsels.

According to Andi Hamzah, evidence which is based on the regulation is characteristically relative. To illustrates, evidence such as witness is actually tend to be blurred and very relative since it is given by the people who have forgetfulness. ${ }^{18}$ This assumption may be the reason for the judge who considered subordinates expert testimony. It can be considered too subjective when it compared to other evidence. However, if it is a reason for judges to reject the expert, I argue that the judges should argumentatively explain their refusal to eliminate the impression that they ignore evidences presented by the parties.

Meanwhile, according to Yahya Harahap, although the value of expert evidence is not binding, the authority of the judges to decide whether or not to use the expert testimony as legal consideration should be exercised responsibly based on moral values. This responsibility is the judge's obligation to realize the truth for law enforcement and legal certainty. Djoko Prakoso is also asserted that the Criminal Procedure Code have determined the expert witness as valid evidence, thus the judges cannot simply exclude it even if it contrasts to his belief.

To this issue, I argue that the judges cannot simply ignore the expert testimony especially when the process of proving the crime needs expert ability beyond the discipline of law. Since the expert testimony can helps the judges in finding the real truth of a criminal case, it plays an important role in the verification processes in the future. Although its characteristic is not binding, it cannot merely be excluded for legal consideration. Hence, the judges should be able to assess the urgency of the expert related to the cases and should also have an argument in accepting or rejecting a statement of the experts.

I agree with Made Hendra stating that the urgency of expert testimony depends on its relevance to the case. The presence of relevant experts make expert evidence not only serve as a supplement or complement of the judge's conviction, but can also be the basis of the judge's conviction. As such, the expert testimony can be more optimal to be used to assist verification processes, particularly in cases related to non-legal discipline.

Moreover, the relevance of the expert with the case should also be measured from the expert qualifications. Expert testimony with proper qualifications would be very valuable evidence and strengthen judges' consideration in deciding the case. Conversely, if the expert does not have the proper qualifications, then the expert testimony becomes meaningless and useless.

\footnotetext{
Jakarta.

18 Hamzah, Andi. Hukum Acara Pidana Indonesia (Indonesian Criminal Procedure Law). 1st Edition. Jakarta: Sinar Grafika, 2001.
} 


\section{Debate among The Experts}

Since the scientific truth is multifaceted, there will be various explanation of a problem. This will lead to debate among the experts that will raise a problem in legal investigation and court examination. In the investigation process, investigators attempt to prove their preliminary evidence in order the case can be transferred into the court. They sometimes use expert testimony that will lead the debate between the parties. Meanwhile in the court examination, both prosecutors and the defendants try to prove their each position that will also lead to the debate.

One example of the debate among experts in the investigation process is in case of mudflow of oil drilling at BanjarPanji1 owned by Lapindo Brantas Inc.(hereinafter referred to as the Lapindo mudflow) in Sidoarjo, East Java. ${ }^{19}$ Investigation of this case was conducted by East Java Regional Police in June2006. There were 13 people who later determined the suspect. To support the investigation, police investigators then inquire number of experts from various fields such as oil and gas mining experts and geologists. Of the twelve experts who testified about the causes of the Lapindo mudflow, there are different opinions. Nine experts declared Lapindo mudflow caused purely by natural disasters, while three other experts stated Lapindo mudflow caused by human error. ${ }^{20}$

Difference opinion of the experts becomes one of the main reasons for the prosecutor who has four times returning investigation file from police investigators. According to junior prosecutor for general crime (Jampidum) Abdul Hakim Ritonga, the conflicting expert testimony will be an obstacle and will become contra productive if it brings to the court. ${ }^{21}$ However, the way prosecutors saw this problem which emphasis on the unity of expert opinion in determining the cause of Lapindo mudflow had made the investigation process last long. On August $5^{\text {th }}, 2009$ police department issued a warrant termination of investigation (SP3) signed by the Director of Criminal Investigation of East Java Police Commissioner Edy Supriyadi. Publishing SP3 file was motivated by the returning file of the prosecutions with the status of P18 or incomplete files. Prosecutors also issued a P-19 (manual prosecutor told the investigator to complete the file) contains a request to the investigator to prove the correlation and causation of mudflow to a radius of 150 meters from the wellbore drilling the Banjar Panjil. However, police said that it was difficult to prove such things as no witnesses during the incident and also assessed no expert can prove the correlation between mudflow and the drilling wells. ${ }^{22}$

${ }^{19}$ Data from Sidoarjo Mudflow Management Agency (BPLS) stated that the mudflow has caused 12 villaged sinked such as Siring, Jatirejo, Mindi, Renokenongo, Kedungbendo, Gempolsari, Kedungcangkring, Pejarakan, Besuki, Gempolsari, Glagaharum, Ketapang, dan Kalitengah. At least 14,000 household or about 40,000 inhabitants in 12 villages have became victims. See "Badan Penanggulangan Semburan Lumpur " http://www.bpls.go.id/index.php? option=com content\&view=article\&id=74:bidang-sosial\&catid $=61$ :umum-sosial $\&$ Itemid=82.

20 "Duduk Bersama Bukan Solusi Selama Persyaratan Belum Terpenuhi Kasus Lapindo (Sitting Together is not the Solution since the Requirement has yet be Completed; Lapindo Case" http:// hukumonline.com/ detail.asp?id=22149\&cl=Berita, retrieved 2 July 2009.

21 "Kejaksaan Belum Temukan Kausalitas Pengeboran dan Semburan Lumpur (The Attorney still not yet Find the Causality between the Drilling and the Mudflow)" http://hukumonline.com/detail. asp?id=19719\&cl=Berita, retrieved 2 July 2009.

22 "Polisi Hentikan Penyidikan Kasus Lapindo (The Police Has Stopped Lapindo Case Investigation)” Kompas, (8 August 2009), p. 2. 
From that case, we can see that expert opinion become one of the considerations to decide the following of the legal proceeding. This is due to the type of knowledge need by the investigators and the prosecutors are very technical and non-legal knowledge. However, I argue that the conflicting of expert opinion should be anticipated before expert selecting process. Expecting the unified opinion to be taken in the legal process is difficult things. Therefore, the role of law enforcer in sorting and selecting information from the experts is very crucial in overcoming the problems.

In Lapindo case, investigators are required to obtain evidences that can convince them of the existence of a criminal case. The existence of the conflicting opinion in assessing the causes of mudflow case should be addressed by presenting an independent expert. But it was less concerned by investigators. Some people, including from Legal Aid Society (LBHM) and the Movement of Lapindo Mud Victims Demand Justice (GMKKLL) considers the investigator have been ignoring a number of geologists from the University of Durham, England, namely Richard Davies and Michael Manga. Both experts have opinion that the mudflow caused by mining activities conducted by PT Lapindo Brantas. Efforts to facilitate investigation by the expert have been done by LBHM and GMKLL, but investigators ignored it. In addition to the two experts, investigators also did not consider the results of world-class geologist meeting held in Cape Town, South Africa by the American Association of Petroleum Geology (AAPG). From here, emerge accusation that this case not only considered as legal case but also political-economy case that involves a conspiracy among law enforcers, politicians, and businessmen. ${ }^{23}$

Cases like Lapindo mudflow showed the indispensable of expert testimony particularly when the investigators could not easily made sense of the technical problems associated with the criminal case. At least, the investigators must also to be objective to accommodate any opinion that can help make clear the criminal cases. The investigators are obliged to collect evidence as optimal as possible although the existing law only determines minimal two evidences that can be used by the judges to make legal decision.

According to Rudy Satriyo Mukantardjo, if there is different opinion of experts on the investigation process, investigators must be able to assess its validity. Similar principle can be applied to the examination process in the court. The different testimony presented by the prosecutors and the defendant should be considered as a normal thing. This is the judges' obligation to analyze which are considered to be true or wrong arguments. Law enforcers should attempt to present the experts that can understandably explain the case, especially for the judges. ${ }^{24}$

Corruption Court judge I Made Hendra argues, if there is disagreement among experts, then the judges should call a third expert as a mediator. However, along his carrier as a corruption court judge he never summoned an expert. ${ }^{25}$ Criminal law expert Chairul Huda assesses that the judge must be able to address the difference opinion of the experts by choosing the strongest argument. To illustrate, if there are two different opinion of criminal law expert in interpreting the law, the judge can

23 "SP3 Kasus Lapindo Diduga Ada Konspirasi (It is Expected there is Conspiration on the SP3 of Lapindo Case)," http://www.hukumonline.com/berita/baca/hol22862/sp3-kasus-lapindo-diduga-adakonspirasi- retrieved 10 Mei 2010. See also Abdil Mughis Mudhoffir, "Berebut Kebenaran: Governmentality pada Kasus Lapindo (Claiming the Truth: Governmentality in Lapindo Case)," (Thesis at the Faculty of Social Science and Political Science Universitas Indonesia, Depok, 2008), p. 9.

${ }^{24}$ Interview with Rudy Satriyo Mukantardjo, a criminal law expert, 25 February 2010, in Depok.

${ }^{25}$ Interview with I Made Hendra Kusuma, a criminal court judge, 11 March 2010, in Jakarta. 
analyze the strongest theoretical interpretation. Moreover, expert testimony can also be assessed by referring to the legal reasoning since the decision is not only based on the book but also based on the reason. Finally, if both opinions are considered false, the judge should also express his opinion. ${ }^{26}$

Maqdir Ismail, also has similar opinion on that case. For him, when there is conflicting testimony in the court, judges can exclude those opinions. However, judges should also find other experts that can convince him to decide the case. Conversely, if the experts from the two parties explain the same thing, then the judge should not ignore it. ${ }^{27}$

Due to the Criminal Procedure Code have yet optimally resolved the problems of expert witness, then it relies on the judge's role. The judge has the authority to determine the appropriate experts and judge should also be able to present experts who can convince him. As the law defines negative proof, the judge's conviction should be based on strong evidences. Thus, the qualification of expert in the examination process should be considered carefully.

To conclude, provision regarding the qualification of experts who testified in the examination process is needed. It is due to the Criminal Procedure Code does not specifically regulated the expert qualification. However, some regulation did it such as law on information technology (UU ITE), a number of internal regulations at Attorney General and the Supreme Court, as well as the decree of the Head of Police that explain this matter can be references for determining the experts who have capacity in accordance with the needs of the criminal proceedings. However, I argue that these regulations are still not able to accommodate issues related to expert testimony in criminal law such as the debate about ius curia novit principle (whether or not the criminal law expert can be presented as an expert witness) as well as related to conflicting opinion of the experts.

In my opinion, Criminal Procedure Code should contain several provisions related to the qualification of experts, for example about what should be considered by a judge to accept or reject expert testimony. In addition, it should also address the debate on the expert opinion that blend in the fact analysis to determine what kind of expert testimony that could be worth as evidence. The upcoming Criminal Procedure Code should also require judges to explain his argument when choosing an expert opinion from another one. Thus, the decision of the judge is getting close to the material truth because of the judge's conviction is built by solid logic. In addition, other regulations outside the Criminal Procedure Code which contains criminal provisions should also regulate about expert testimony. Moreover, if the crime has the new form due to the advancement of science and technology, then the law should also be able to explain the expert qualifications that particularly needed. If it is not possible or is deemed too technical, it should set a partnership with agencies that could be a reference to bring relevant expertise. Thus, the expert qualifications necessary for the criminal proceedings can be clear guidelines for law enforcement.

\section{The Partiality of Experts}

Normatively, due to his expertise an expert witness is required to be as objective as possible in explaining a problem. In fact, the expert testimony presented in trial is

\footnotetext{
${ }^{26}$ Interview with Chairul Huda, a criminal law expert, 15 March 2010, in Jakarta.

${ }^{27}$ Interview with Maqdir Ismail, a lawyer, 25 February 2010, in Jakarta.
} 
almost always benefiting those who submit. At that moment, the claim of neutrality and objectivity of the expert often questioned, especially by the aggrieved the party aggrieved by the expert testimony.

Maqdir Ismail a lawyer assesses the objectivity of experts as an important point because ideally expert testimony is an impartial opinion. Science should be neutral and objective to proclaim the truth. He also assesses that the value of expert opinion is similar to the doctrine presented in court. Thus, the expert's statement should be accepted as a form of truth to complete the factual truth. Maqdir claimed that he almost always presented expert in criminal cases to maintain the objectivity of the trial.

Factually in court, Maqdir cannot deny that the experts benefiting the party who present them. However, Maqdir assess the objectivity of experts still exist because the theoretical approach conducted by experts in understanding a case is more objective than a judge or prosecutor or legal counsel. Even if the proposed expert testimony more relieves the defendant, it is because the experts get information about the case from that side. When there is debate among experts presented by the prosecutors and defense counsels, then it is merely a matter of freedom of thought by experts. Maqdir said that he usually presented experts who are scientists, in contrast to the general prosecutor who brings experts from government agencies. For example in recruiting financial experts, prosecutors took the experts from the Financial and Development Supervisory Agency (BPKP) and expert authentication of Forensic Police Headquarters. ${ }^{28}$

In selecting experts, Sarjono Turin a prosecutor of the commission of combating corruption (KPK) claims that he always brings an independent expert and not partial to any party that can provide objective information. To assess the objectivity of the expert, the commission will examine the background and experience of experts, ranging from formal and non-formal educational background to the experience of providing expert testimony in the trial. Sarjono also claims that he avoid selecting experts with the consideration that the experts have opinions that could incriminate the accused. Sarjono claims that it upholds the principle of equality before the law, so it does not directly assess the defendant guilty. It also confirmed by other prosecutor Dwi Aries Sudarto that according to him expert ideally must stand on the basis of their knowledge so that there is no incriminating expert or experts who relieve the defendant. $^{29}$

Criminal law expert Chairul Huda stated that any information given in court is a neutral opinion. From his experience, he gave testimony in court that usually also be used by the prosecution and defense counsel. Thus, although Chairul presented by the defendant, a statement can also be used to strengthen the prosecution charges.

"Occasionally, when the prosecutor was not ready then he cannot ask the questions that will strengthen the indictment. Or he thought that this is the expert of the defendant, therefore there is no point to ask and that it will definitely benefit the accused. Or he considered that there should be no expert in this case. So, lots of facts showing this. So he did not ask, although there are a lot of things that could be asked".30

${ }^{28}$ Interview with Maqdir Ismail, 25 February 2010, in Jakarta.

${ }^{29}$ Interview with Sarjono Turin dan Dwi Aries Sudarto, prosecutors of the commission of combating corruption (KPK), 11 March 2010, in Jakarta.

${ }^{30}$ Interview Chairul Huda, a criminal law expert, 15 March 2010, in Jakarta. 
Objectivity in conveying information is also a concern of criminal law expert Rudy Satriyo Mukantardjo. Based on his experience, there are judges who consider his statement as it is still seen in a neutral position, not in favor of either party. However, Rudy admits that the objectivity of experts who presented one of the parties will be difficult to be accepted by the other party.

For I Made Hendra Kusuma, a corruption court judge, objective stand of experts in stating the scientific truth is not the obligation. It is different with the information stated by the witness that obliges to say the truth. ${ }^{31}$ Experts were asked to provide information only on accordance with their expertise, but the judge does not demand the truth from them. I Made Hendra does not concern with the partiality of the experts and does not limit the expert testimony, as long as the information submitted is still within the competence of the experts. However, I Made Hendra still considers the objectivity of experts who testified. If the statements of the experts are still objective and normative, then the judge will consider it because the judge has the authority to assess all the facts that appear in the trial. According to I Made Hendra, the Criminal Procedure Code has provided a benchmark in the form of free probative value on the testimony of an expert because there is always a tendency of experts convey information that is not objective. To avoid partiality of the experts, the judge is given free evidentiary value which will be assessed whether or not it may be used.

Made Hendra's opinion is not contradict with the Criminal Procedure Code which does not specify explicitly what should be the attitude of experts. The Code also does not provide a sanction if the expert testified is not objective. Until now there is no expert who is ethically sanctioned by his professional organizations due to his objectivity in the trial. The parameter of objectivity is very relative which makes it likely to be a matter of morality and responsibility to the science.

According to Mardjono Reksodiputro, objectivity means honesty to himself and to science. However, experts do not have the obligation to provide information that is acceptable to both parties. Reksodiputro also argues that in the court experts only oblige to provide information in accordance with its portion. It means the expert testimony is partially in accordance with the party's interest who submits them, and experts are not obliged to pass on information from the perspective of the opposing party who presented it.

"It is not his obligation to bring up the image of the right side of the coin (the opponent). He is only obliged to bring up the image of left side of the coin (those who summoned). It may be said that he paid for. But, he must be honest to science."32

In contrast to that opinion, Surastini Fitriasih question in what extent the experts should experts their argument. There are two possibilities of experts' position: give information objectively based on his knowledge or conclude a case in accordance with its portion like relieving party that summoned them. She also questions how should the experts answering the questions that could harm the party who presented them. Should the experts be honest or hide the information that can benefit the opponent? ${ }^{33}$

However, I argue that if the objectivity means as the honesty to the science, experts should not hide the truth in the trial although it harms the party who presented them.

${ }^{31}$ I Made Hendra refers to the oath of a witness and expert witness. Thw witness oat state that: "... by this will say the truth, nothing but the truth". Meanwhile, the oath spell by expert witness is: “... gives opinion based on my knowledge as well as possible".

${ }^{32}$ Mardjono Reksodiputro's opinion stated in the thesis examination, 24 June 2010, in Jakarta.

${ }^{33}$ This critics stated by Surastini Fitriasih in the thesis examination, 24 June 2010, in Jakarta. 
According to Michael Ruse, an expert who give testimony for the law, still have the freedom of thought that correspond to the science. Ruse assesses that the experts do not have the legal responsibility for the information they convey as experts asked to attend the trial based on his expertise.

The emphasis must surely be on the fact that the expert gives his/her professional opinion. This statement does not mean that you can say anything you feel like saying -or even everything that you personally believe. What does it mean is that you, as a philosopher (or whatever), can say what you think reasonable, in the light of your specialized knowledge, as a philosopher (or whatever). It is not necessary that everyone in your discipline agree with you. ${ }^{34}$

That statement indicates that the freedom of thought is attached to the experts, despite their presence in the court is an initiative of such party. Freedom of speech of the experts can also be regarded as an objective value that is expected to help the process of law impartially. Moreover, objectivity of expert is neither an absolute musthave thing nor the things that determined by law, but can be one measure in assessing the credibility of the experts.

As a scientist, he could have claimed that his explanation is based on a rigorous methodology, and therefore his statement is objective. Moreover, the recognition of someone as an expert can also be considered that his explanation is objectivity principles of the science. However, if the information is almost always benefiting those who submitted it, then it becomes irrelevant if the experts claim his statement as a scientific truth that is free from all prejudice and partiality.

\section{VI.Conclusion}

In the Criminal Procedure Code, experts only described as a person who has special skills that can make light of a crime, without further determine how an individual's expertise is measured. However, some internal regulation in the law enforcement community began addressing the need to determine the qualification of experts. Meanwhile, the phenomenon of differentiation and specialization in the field of law, have made the principle of ius curia novit cannot be interpreted rigidly. Moreover, the development of new legislation also contains criminal provisions regarding new problems, such as election crime, cyber crime, banking criminal acts, and so forth. Moreover, criminal law expert who specializes on certain issue will be more relevant to give testimony in the court than those who only mastering general criminal law.

Thus, the rejection of presenting the criminal law experts in the court due to the principle of ius curia novit cannot be accepted. It is also because there is no clear definition on what extent the criminal expert contradicts with that principle. Moreover, the Criminal Procedure Code also does not mention any specific explanation about expert testimony. Although the opinion of law enforcement differ from each other in addressing the existence of criminal law experts and judges are free to decide to accept or reject the criminal law expert, but the judge cannot simply ignore the criminal law expert testimony only by the reason of ius curia novit.

Related to the debate of expert opinion, the Criminal Procedure Code also does not accommodate it as something that should be anticipated in the criminal proceedings.

${ }^{34}$ Michael Ruse, "Commentary: The Academic as Expert Witness," Science, Technology, \& Human Values Vol. 11 No. 2 (Spring, 1986). Hlm. 68-73 
Meanwhile, the development of science has led to a variety of scientific opinion. If science comes from the field of non-law, then law enforcement will be difficult to choose which one is the most correct opinion. Although there is no single scientific truth, but it should be decide what opinion which can be considered the most right to be evidence. Since the provisions of the Criminal Procedure Code cannot resolve the problems concerning expert testimony optimally, then the solution depends on law enforcement policy.

To this case, the judge could also bring other experts as a comparison between the two contradiction opinions. The judge has the authority to determine the qualifications of experts who are considered to have expertise that can convince him. As the law defines negative proof, the judge's conviction should be based on strong evidences. If the explanation of an expert who challenged other experts becomes the consideration of the judge, then the judge should have arguments about these choices.

It is also argued that the conflicting opinion of the experts that will arise more frequently in the future can be resolved by carefully considering expert qualification. The qualifications which are considered from various aspects can increase confidence in dealing with the information given. Academic history and experience of experts, as well as moral attitudes associated with science can be indicators to measure the qualification and objectivity of the experts. Thus, law enforcement has no doubt to the expert testimony as evidence that can help make light of a criminal offense.

However, on some occasion it should also be considered that expert alignments are reasonable because most experts presented with a tendency to support the arguments of the parties who submitted them. Although it is not prohibited by the Criminal Procedure Code, but on the other hand, the partiality of the expert can be a problem in getting the material truth. That is because the expert testimony has power as evidence that could be considered by a judge to declare someone guilty or not guilty. Ideally, an expert has an objective attitude which is generally assessed on the consistency and neutrality in accordance with the opinion of expertise. Therefore, in certain cases expert alignments often questioned because they have been disturbing sense of justice in society. However expert alignments generally are difficult to be measured since it is just as the claims of the parties who do not agree or are harmed by the expert testimony.

Moreover, expert alignments cannot also be separated from the goals to be achieved both by experts and by party who summoned them. Does an expert oblige to testify their ideas and help the process of verification, or just to get money? The fact of highly-paid expert that influence their scientific position to give information as desired by parties presented them indicates that there is a partial and subjective expert testimony.

\section{Bibliography}

Apeldoorn, LJ van. Pengantar Ilmu Hukum(Introduction to Legal Science). Cet. 25. Jakarta: Pradnya Paramita, 1993.

Atmasasmita, Romli. Bunga Rampai Hukum Acara Pidana(Anthologi of Criminal Procedure Law). Bandung: Binacipta, 1983.

Badan Pembinaan Hukum Nasional. Analisis dan Evaluasi Hukum Tentang Wewenang Kepolisian dan Kejaksaan di Bidang Penyidikan(Legal Analysis and Evaluation on the Authority of Police and Attorney in the Investigation). Jakarta: Badan Pembinaan Hukum Nasional, 2003. 
Creswell, John W. Research Design, Quantitative and Qualitative Approaches. London: Sage Publication, 2003.

Fienberg, Stephen E. "Ethics and the Expert Witness: Statistic on Trial." Journal of the Royal Statistical Society. Series A (Statistics in Society) Vol. 160 No. 2 (1997): 321-331.

Hamzah, Andi. Hukum Acara Pidana Indonesia (Indonesian Criminal Procedure Law).1st Edition. Jakarta: Sinar Grafika, 2001.

Hansen, Mark. "Battle of the Expert." American Bar Asssociation (ABA) Journal Vol. 91 (December 2005): 52.

Harahap, M Yahya. Pembahasan Permasalahan dan Penerapan KUHAP; Pemeriksaan Sidang Pengadilan, Banding, Kasasi, dan Peninjauan Kembali(Study on Problem and Implementation of Criminal Procedure Code; Court Examination, Appealing, and econsideration). Cet.2. Jakarta: Sinar Grafika, 2001.

Pembahasan Permasalahan dan Penerapan KUHAP; Penyidikan dan Penuntutan(Study on the Problem and Implementation of Criminal Procedure Code: Investigation and Prosecution. Cet. 4. Jakarta: Sinar Grafika, 2002.

Herbst, Ludmilla. "Evolving Court Rules on Expert Evidence." Canadian Property Valuation Vol. 54 (2010): 17.

Howard, MN. Ed. Phipson on Evidence.Fifteenth Edition. London: Sweet \& Maxwell Limited, 2000.

Ihsan. "Peranan Kesaksian Ilmiah (Scientific Testimony) dalam Penyidikan Suatu Tindak Pidana." Tesis, Magister Hukum Universitas Indonesia. Jakarta, 2006.

Kalman, David \& David L Eaton. "Scientists in the Courtroom: Basic Pointers for the Expert Scientific Witness." Environmental Health Perspectives Vol. 102 No. 8 (August, 1994): 668-672.

Kansil, CST. Pengantar Ilmu Hukum dan Tata Hukum Indonesia(Introduction to Legal Science and Indonesian Legal System). 8th Edition. Jakarta: Balai Pustaka, 1989.

Koemolontang, BZ dan T Nasrullah, Hukum Acara Pidana(Ciminal Procedure Law). Depok: Fakultas Hukum Universitas Indonesia, 1993.

Kousser, J Morgan. "Are Expert Witnesses Whores? Reflections on Objectivity in Scholarship and Expert Witnessing." The Public Historian Vol. 6 No. 1 (Winter, 1984): 5-19.

Loftus, Elizabeth F. "Ten Years in the Life of an Expert Witness." Law and Human Behavior Vol. 10, No. 3 (September 1986): 241-263.

Loqman, Loebby. Kekuasaan Kehakiman; Tinjauan dari Segi Hukum Acara Pidana(Authority of Judge; Review from Criminal Procedure Law).Jakarta: Datacom, 1990.

Loudoe, John Z. Fakta dan Norma dalam Hukum Acara(Facts and Norms in Procedure Law).1st Edition. Surabaya: Bina Aksara, 1984.

Machmudin, H Dudu Duswara. "Peranan Keyakinan Hakim dalam Memutus Suatu Perkara di Pengadilan (The Role of Judge in Deciding a Case in The Court)." Varia Peradilan Tahun ke-XXI No. 251 (October 2006): 51- 66.

Mamudji, Sri et al. Metode Penelitian dan Penulisan Hukum(Legal Research and Writing Method). 1st Edition. Jakarta: Badan Penerbit Fakultas Hukum Universitas Indonesia, 2005.

Manan, Bagir. "Beberapa Catatan Tentang Penafsiran (Some Notes on Interpetation)." Varia Peradilan Tahun ke-XXIV No. 285 (Agustus 2009): 5-14.

Moeljatno. Asas-asas Hukum Pidana(The Principles of Criminal Law). Jakarta: PT. Bina Aksara, 1984. 
Morawski, Lech. "Law, Fact and Legal Language." Law and Philosophy Vol. 18 No. 5 (September 1999): 461-473.

Mudhoffir, Abdil Mughis. "Berebut Kebenaran: Governmentality Pada Kasus Lapindo (Claiming the Truth: Governmentality in Lapindo Case)." Master Thesis at Faculty of Social Science and Political Science Universitas Indonesia. Depok, 2008.

Mulyadi, Lilik. Hukum Acara Pidana; Normatif, Teoritis, Praktik dan Permasalahannya(Criminal Procedure Law; Normative, Theoretical, Practical, and Its Problems). 1st Edition. Bandung: Alumni, 2007.

Munthe, Saut Erwin Hartono A. "Tinjauan Yuridis terhadap Kekuatan Pembuktian Keterangan Saksi Melalui Teleconference Dalam Proses Persidangan Perkara Pidana(Critical Review on The Stength of Evidence of Witness through Teleconference in Criminal Court Room)." Tesis, Magister Hukum Universitas Indonesia. Jakarta, 2004.

Neuman, W. Lawrence. Social Research Methods Quantitative and Qualitative Methods. Boston: Allyn and Bacon, 1997.

Nuryanto. "Penanganan Akibat Bencana Luapan Lumpur Panas PT Lapindo Brantas di Kecamatan Porong oleh Polres Sidoarjo (Handling of The Effect of Lapindo Mudflow in Porong by Sidoarjo Police Resort)." Master Thesis at Police Science Study Universitas Indonesia. Jakarta, 2007.

Pangaribuan, Luhut MP. Hukum Acara Pidana; Satu Kompilasi Ketentuan-Ketentuan KUHAP Serta Dilengkapi dengan Hukum Internasional yang Relevan(Criminal Procedure Law: A Compilation on Criminal Procedure Code's provisions with Relevant International Law). 1st Edition. Jakarta: Djambatan, 2000.

Poernomo, Bambang. Pola Dasar Teori-Asas Umum Hukum Acara Pidana dan Penegakan Hukum Pidana(Basic Theori: Principles of Criminal Procedure Law and the Enforcement of Criminal Law). 1st Edition. Yogyakarta: Liberty, 1993.

Prakoso, Djoko. Alat Bukti dan Kekuatan Pembuktian di Dalam Proses Pidana(Evidence and The Strength of Ecidence). 1st Edition. Yogyakarta: Liberty, 1988.

Prodjohamidjojo, Martiman. Kemerdekaan Hakim; Keputusan Bebas Murni (Arti dan Makna)(Judge Freedom: Released Decision, Definition and Meaning). Jakarta: Simplex, 1984.

Pembahasan Hukum Acara Pidana dalam Teori dan Praktek(Study on The Criminal procedure Law Theoretically and Practically). Jakarta: Pradnya Paramita, 1989.

Komentar Atas Kitab Undang-Undang Hukum Acara Pidana(Some Comments on Criminal procedure Code). 3rd Edition. Jakarta: Pradnya Paramita, 1990.

Prodjodikoro, R Wirjono. Hukum Acara Pidana di Indonesia(Criminal Procedure Law in Indonesia).12nd Edition. Bandung: Sumur Bandung, 1985.

Prodjohamidjojo, Martiman. "Sumpah atau Janji (Oath and Promise)," Varia Peradilan Tahun III No. 29 (Februari 1988): 176-178.

Rahardjo, Satjipto. Ilmu Hukum(Legal Science).5th Edition. Bandung: Citra Aditya Bakti, 2000.

Sisi-sisi Lain dari Hukum di Indonesia(The Other Side of Law in Indonesia). 2nd Edition. Jakarta: Penerbit Buku Kompas, 2006.

Biarkan Hukum Mengalir(Let The Law Flow). 1st Edition. Jakarta: Penerbit Buku Kompas, 2007.

Ranoemihardja, R Atang. Hukum Acara Pidana(Criminal Procedure Law). Bandung: Tarsito, 1980.

Reksodiputro, Mardjono. "Survai dan Riset untuk Sistem Peradilan Pidana yang 
Lebih Rasional (Survey and Research for Criminal Justice System to be More Rational)." in Kriminologi dan Sistem Peradilan Pidana; Kumpulan Karangan Buku Kedua(Criminology and Criminal Justice System; Anthology of Writing Second Book). Jakarta: Pusat Pelayanan Keadilan dan Pengabdian Hukum, 2007, p. 97-115.

Remmelink, Jan. Hukum Pidana; Komentar atas Pasal-pasal Terpenting dari Kitab Undang-Undang Pidana Belanda dan Padanannya dalam Kitab UndangUndang Hukum Pidana Indonesia(Criminal Law: Some Comments on The Most Important of Dutch Criminal Procedure Code and The Equivalent with Indonesian Criminal Procedure Code). Translated by Tristan Pascal Moeliono. Jakarta: Gramedia Pustaka Utama, 2003.

Rostant, Derek. "Reviewing the Role of Expert Witnesses." CA Magazine (March 2010): 10.

Ruse, Michael. “Commentary: The Academic as Expert Witness," Science, Technology, \& Human Values Vol. 11 No. 2 (Spring, 1986): 68-73

Samosir, C Djisman. Hukum Acara Pidana dalam Perbandingan(Comparison of Criminal Procedure Law). 2nd Edition. Bandung: Binacipta, 1986.

Sargent, John E. "Understanding the Role of a Vocational Expert." The Practical Litigator (November 2009): 41-48.

Seno Adji, Indriyanto. Hukum dan Kebebasan Pers(Law and Press Justice). 1st Edition. Jakarta: Penerbit Diadit Media, 2008.

Seno Adji, Oemar. Hukum (Acara) Pidana dalam Prospeksi(Prospecting of Criminal Procedure Code). Jakarta: Erlangga, 1981.

Siregar, Bismar. Hukum Acara Pidana(Criminal Procedure Law). 1st Edition. Jakarta: Badan Pembinaan Hukum Nasional Departemen Kehakiman,1983.

Soekanto, Soerjono dan Sri Mamudji. Penelitian Hukum Normatif; Suatu Tinjauan Singkat(Normative Legal Research: Short Review). Jakarta: RajaGrafindo Persada, 2007.

Soeparmono, R. Keterangan Ahli dan Visum et Repertum dalam Aspek Hukum Acara Pidana(Expert Witness and Visum et Repertumin Some Aspects of Criminal Procedure Law). Cet. 2. Semarang: Mandar Maju, 2002.

Soesilo, R. Hukum Acara Pidana (Prosedur Penyelesaian Perkara Pidana Menurut KUHAP bagi Penegak Hukum)(Procedure of Completion on Criminal Case based on Criminal Procedure Code for Law Enforcers). 1st Edition. Bandung: Karya Nusantara, 1982.

Soetomo, A. Hukum Acara Pidana Indonesia dalam Praktek(Indonesian Criminal Procedure Code in Practice). 1st Edition. Jakarta: Pustaka Kartini, 1990.

Tanusubroto, S. Dasar-Dasar Hukum Acara Pidana(The Basic of Criminal Procedure Law). 2nd Edition. Bandung: Armico. Cet. 2, 1989.

Taylor, Alan. Principles of Evidence. 2nd Ed. London: Cavendish Publishing Limited, 2000.

The Harvard Law Review Associaton. "Expert Legal Testimony," Harvard Law Review Vol. 97 No. 3 (January 1984): 797-814.

"Reliable Evaluation of Expert Testimony." Harvard Law Review Vol. 116 No. 7 (May, 2003): 2142-2163.

Trusov, Alexei. An Introduction to The Theory of Evidence. Moscow: Foreign Languages Publishing House Moscow, tanpa tahun.

Yudowidagdo Hendrastanto, et al. Kapita Selekta Hukum Acara Pidana di Indonesia(Anthology of Criminal Procedure Law in Indonesia). 1st Edition. Jakarta: Bina Aksara, 1987. 
Van Rhee, CH. Ed. European Tradition in Civil Procedure. Oxford: Intersentia Antwerpen, 2005.

\section{Dictionary}

Black, Henry Campbell. Black's Law Dictionary. Sixth Edition. St.Paul: West Publishing Co., 1990.

Curzon, LB. Dictionary of Law. Sixth Edition. Essex: Pearson Education Limited, 2002.

Garner, Bryan A. Ed. Black's Law Dictionary.Eight Edition. St. Paul: West Publishing Co., 2004.

McKechnie, Jean L. Ed. Webster's New Twentieth Century Dictionary Unabridged. Second Edition. New York: New World Dictionaries/Simon and Schuster, 1983.

Statsky, William. Legal Thesaurus/Dictionary. St. Paul: West Publishing Co., 1985.

Subekti R dan Tjitrosoedibio. Kamus Hukum(Legal Dictionary). 10th Edition. Jakarta: Pradnya Paramita, 1989.

Sudarsono. Kamus Hukum(Legal Dictionary).2nd Edition. Jakarta: Rineka Cipta, 1999.

Tim Penyusun Kamus Pusat Pembinaan dan Pengembangan Bahasa. Kamus Besar Bahasa Indonesia(Indonesian Dictionary). 1st Edition. Jakarta: Balai Pustaka, 1988.

Tim Redaksi Tatanusa. Kamus Istilah Menurut Peraturan Perundang-undangan Republik Indonesia 1945-2007(Term Dictionary according to Law and Regulatuons in Indonesia 1945-2007). 1st Edition. Jakarta: Tatanusa, 2008.

\section{Internet}

"Duduk Bersama Bukan Solusi Selama Persyaratan Belum Terpenuhi Kasus Lapindo (Sitting Together is not the Solution since the Requirement has yet be Completed; Lapindo Case" http:// hukumonline.com/ detail.asp?id=22149\&cl=Berita, retrieved 2 July 2009.

"Kejaksaan Belum Temukan Kausalitas Pengeboran dan Semburan Lumpur (The Attorney still not yet Find the Causality between the Drilling and the Mudflow)" http://hukumonline.com/detail.asp?id=19719\&cl=Berita, retrieved 2 July 2009.

"Polisi Hentikan Penyidikan Kasus Lapindo (The Police Has Stopped Lapindo Case Investigation)" Kompas, (8 August 2009), p. 2.

"SP3 Kasus Lapindo Diduga Ada Konspirasi (It is Expected there is Conspiration on the SP3 of Lapindo Case)," http://www.hukumonline.com/berita/baca/ hol22862/sp3-kasus-lapindo-diduga-ada-konspirasi- retrieved 10 Mei 2010.

\section{Regulations}

Kitab Undang-undang Hukum Pidana (Wetboek van Strafrecht voor Nederlandsch Indie) (Criminal Procedure Code). Trnslated by R. Soesilo. Bogor: Politeia, 1996.

Kitab Undang-Undang Hukum Acara Pidana(Criminal Procedure Code), UU No. 8 Tahun 1981. Disusun oleh M Karjadi dan R Soesilo dalam Kitab UndangUndang Hukum Acara Pidana dengan Penjelasan Resmi dan Komentar(Criminal Procedure Code with Official Explanations and Comments). 3rd Edition. Bogor: Politeia, 1997.

Indonesia. Undang-Undang Dasar Negara Republik Indonesia Tahun 1945.

Undang-Undang tentang Pers(Press Law), UU No. 40 Tahun 1999, LN No. 166 Tahun 1999,TLN No. 3887. 
Undang-Undang tentang Kekuasaan Kehakiman(Judge Authority Law), UU No. 4 Tahun 2004, LN No. 8 Tahun 2004. TLN No. 4358.

Undang-Undang tentang Informasi dan Transaksi Elektronik(Electronic Information and Transaction Law). UU No. 11 Tahun 2008, LN No. 58 Tahun 2008. TLN No. 4843.

Undang-Undang tentang Pengadilan Tindak Pidana Korupsi(Law on Corruption Crime Court), UU No. 46 Tahun 2009, LN No. 155 Tahun 2009. TLN No. 5074.

Indonesia. Peraturan Pemerintah tentang Pelaksanaan KUHAP(Regulation on the Implementation of Criminal Procedure Code). PP No. 27 Tahun 1983, LN No. 36 Tahun 1983. TLN No. 3258

Keputusan Menteri Kehakiman tentang Tambahan Pedoman Pelaksanaan Kitab Undang-Undang Hukum Acara Pidana (Justice Ministerial Decree on Additional Guidance on The Implementation of Criminal Procedure Code), Nomor M.14PW.07.03 Tahun 1983.

Putusan Mahkamah Konstitusi (Constitutional Judge Decree) Number 061/PUUII/2004 on The Examination of Article 16 of Undang-Undang No. 4 Tahun 2004 Tentang Kekuasaan Kehakiman (Judge Authority).

Rancangan Undang-Undang Tentang Hukum Acara Pidana (Draft Bill on Criminal Procedure Code). 2009.

Kejaksaan Agung, Surat Edaran Jaksa Agung tentang Keterangan Ahli Mengenai Tanda Tangan dan Tulisan Sebagai Alat Bukti (Prosecutor's Circular on Expert Testimony about Signature and Writing as Evidence). SE No. 003/J.A./1984

Mahkamah Agung, Surat Edaran Mahkamah Agung tentang Meminta Keterangan Saksi Ahli Dewan Pers (Supreme Court's Decree on Asking Expert Evidence of Press Council). SEMA No. 13 Tahun 2008 